\title{
PENGARUH PROFITABILITAS, UKURAN PERUSAHAAN DAN KEBIJAKAN DIVIDEN TERHADAP NILAI PERUSAHAAN
}

\author{
Ahmad Romadhani ${ }^{1}$ Muhammad Saifi $^{2}$, Nila Firdausi Nuzula ${ }^{3}$ \\ Fakultas Ilmu Administrasi Universitas Brawijaya, Malang, Jawa Timur, Indonesia \\ Email : ahmadromadhani@gmail.com¹, Msaifi@ub.ac,id², nilafia@ub.ac.id ${ }^{3}$
}

\begin{abstract}
The purpose of this review is to find out the amounts of profit, company size, and dividend policy which can influence the company's value. LQ45 which is listed in Indonesian Stock Exchange is in the year of 2015 - 2018. This research is using Explanatory Research with quantitative approach. The sampling technique is using purposive sampling. Profitability is a financial method used to gauge company's profit. Company's profit that comes from sales and investment return, can influence the company's size. The company's scale is an important information, used by investor who wants to invest their wealth to the company. The magnitude of company can influence dividend return. Company's profit can affect the size of company and dividend return. It can be reflected in the increasing of company' value. The performance of company can be a parameter used by investor to do an investment or funding to the company.
\end{abstract}

Keywords: Profitability, firm size, Dividend policy, firm value.

\begin{abstract}
Tujuan penelitian ini adalah untuk mengetahui pengaruh besarnya keuntungan, ukuran perusahaan dan kebijakan dividen yang dapat mempengaruhi nilai perusahaan $L Q 45$ yang terdaftar di BEI Tahun 2015-2018. Jenis penelitian tersebut menggunakan explanatory reaseacrh dengan pendekatan kuantitatif sedangkan teknik pengambilan sampling menggunakan purposive sampling. Profitabilitas perusahaan merupakan metode keuangan untuk mengukur pendapatan perusahaan baik dari hasil penjualan produk ataupun tingkat pengembalian investasi. Tingkat keuntungan itu mempengaruhi besarnya skala perusahaan. Skala ukuran perusahaan adalah informasi penting bagi investor yang ingin melakukan investasi diperusahaan terkait dan ukuran perusahaan itu akan sangat mempengaruhi tingkat pengembalian dividen dan investasi. Tingkat keuntungan perusahaan bisa dikatakan mempunyai dampak bagi ukuran perusahaan dan tingkat pengembalian dividen dapat tercemin melalui peningkatan nilai perusahaan sehingga kinerja perusahaan tersebut dapat digunakan sebagao parameter bagi investor untuk melakukan pendanaan atau investasi.
\end{abstract}

Keywords: Profitabilitas, Ukuran Perusahaan, Kebijakan Dividen, Nilai Perusahaan. 


\section{PENDAHULUAN}

Dewasa ini dunia bisnis Indonesia semakin pesat dan didukung dengan kemajuan ilmu pengetahuan dan teknologi, maka pertumbungan bisnis dapat semakin kompleks. Fenomena pertumbuhan bisnis ini dapat dilihat dari lahirnya perusahaan-perusahaan baru baik berskala menengah atapun keatas. Pertumbahan perusahaan tersebut bisa mengakibatkan tumbuhnya persaingan bisnis dari segala sektor, sehingga hal itu mendorong perusahaan untuk menciptakan inovasi baru terhadap produkproduknya dan perusahaan perlu memaksimalkan kinerja operasionalnya lebih efektif dan efisien. Oleh karena itu untuk menjalankan strategi tersebut perusahaan memerlukan investasi yang besar agar dapat mewujudkan tujuan perusahaan tersebut.

Secara umum persaingan perusahaan dalam dunia bisnis merupakan hal yang biasa terjadi pada perjalanan perusahaan tersebut. Namun, bila perusahaan dapat menguasai persaingan bisnis sejenis maka perusahaan itu akan mendapatkan profit yang tinggi dan mempunyai nilai ekonomis baik. Indonesia sendiri mempunyai banyak sektor yang dimana setiap industry selalu timbul persaingan bisnis dan hal ini dapat menarik investor asing untuk melakukan investasi pada perusahaan itu sendiri, hal ini dapat dilihat melalui table pembiyaan perusahaan start up pada negara ini sebagai berikut :

Tabel 1

Pembiyaan perusahaan start up di Indonesia

\begin{tabular}{|c|c|c|c|c|}
\hline $\begin{array}{l}\mathbf{N} \\
\mathbf{O}\end{array}$ & Sektor & $\begin{array}{l}\text { Perusahaa } \\
\text { n }\end{array}$ & $\begin{array}{l}\text { Total } \\
\text { pendanaa } \\
\text { n }\end{array}$ & $\begin{array}{l}\text { Unduhan } \\
\text { Android }\end{array}$ \\
\hline \multirow[t]{2}{*}{1} & \multirow[t]{2}{*}{$\begin{array}{l}\text { Ride } \\
\text { Hilling }\end{array}$} & Go-jek & $\begin{array}{l}\$ 3,3 \\
\text { miliar+ }\end{array}$ & $10.000 .000+$ \\
\hline & & Grab & $\begin{array}{l}\$ \quad 6,6 \\
\text { miliar+ }\end{array}$ & $50.000 .000+$ \\
\hline \multirow[t]{3}{*}{2} & \multirow[t]{3}{*}{ Fintech } & $\begin{array}{l}\text { Emtek } \\
\text { Group, } \\
\text { Alibaba } \\
\text { Dana) }\end{array}$ & - & $500.000+$ \\
\hline & & $\begin{array}{l}\text { Go-jek } \\
\text { Go pay) }\end{array}$ & $\begin{array}{l}\$ 3,3 \\
\text { miliar+ }\end{array}$ & $10.000 .000+$ \\
\hline & & $\begin{array}{l}\text { Lippo } \\
\text { Group } \\
\text { (OVO) }\end{array}$ & - & $5.000 .000+$ \\
\hline \multirow[t]{2}{*}{3} & \multirow[t]{2}{*}{ Travel } & Traveloka & $\$ 2$ miliar+ & $10.000 .000+$ \\
\hline & & Tiket com & $\begin{array}{l}\text { Tidak } \\
\text { diketahui, } \\
\text { exit } \\
\text { melalui } \\
\text { akuisisi } \\
\text { blibli } \\
\end{array}$ & $5.000 .000+$ \\
\hline
\end{tabular}

\begin{tabular}{||l|l|l|l|l|}
\hline 4 & $\begin{array}{l}e- \\
\text { commerc } \\
\end{array}$ & $\begin{array}{l}\text { Bukalapak } \\
\text { (Emtek } \\
\text { Group) }\end{array}$ & - & $10.000 .000+$ \\
\cline { 3 - 5 } & $\begin{array}{l}\text { Lazada } \\
\text { (Alibaba } \\
\text { Group) }\end{array}$ & $\$ 2$ miliar+ & $\begin{array}{l}100.000 .000 \\
+\end{array}$ \\
\cline { 3 - 5 } & $\begin{array}{l}\text { Shoope } \\
\text { (Sea } \\
\text { Group) }\end{array}$ & $\begin{array}{l}\text { \$ 500 } \\
\text { miliar+ }\end{array}$ & $50.000 .000+$ \\
\cline { 3 - 5 } & $\begin{array}{l}\text { Tokopedia } \\
\text { (Softbank) }\end{array}$ & $\begin{array}{l}\text { \$ 1,1 } \\
\text { miliar+ }\end{array}$ & $50.000 .000+$ \\
\hline
\end{tabular}

Sumber : data diolah, 2019

Table 1 merupakan pendanaan atau investasi pada sektor start up yang nantinya melalui pendanaan ini perusahaan dapat mengembangkan usahanya dengan lebih baik, sehingga hal ini dapat dilihat dari besarnya pembiayaan asing di beberapa perusahaan start up tersebut. Empat sektor itu mempunyai keunggulan masing-masing yang bisa digunakan sebagai keunggulan utama untuk bersaing di sektor yang sama dan keunggulan tersebut terbukti dapat mengundang minat investor untuk melakukan pendanaan atau investasi di perusahaan terkait. Alasan utama investor asing untuk melakukan pendanaan dikarenakan besarnya peminat masyarakat terhadap pelayanan perusahaan start up dan hal ini dapat menimbulkan persaingan yang kompetitif. Fenomena persaingan bisnis ini merupakan dampak dari fluktuatifnya pertumbuhan perekonomian Indonesia selama tahun 2015-2018 yang nantinya berimbas pada kinerja perusahaan, hal ini dapat dilihat melalui laporan tahunan perusahaan LQ 45 tahun 20152018 yang mengalami penurunan kinerja perusahaan (idx.com). Permasalahan ini menunjukan bahwa perusahaan membutuhkan sebuah pengelolahan keuangan dan keunggulan kompetitif yang dapat digunakan untuk menjalankan aktivitas bisnisnya.

Competitive advantage bagi perusahaaan sangatlah penting karena dengan adanya metode ini perusahaan akan lebih mudah bersaing, namun perusahaan harus mengetahui terlebih dahulu mengenai keunggulan perusahaan yang dapat digunakan sebagai keunggulan dalam menghadapi persaingan bisnis itu. Metode ini mempunyai keunggulan yaitu sejauh mana perusahaan di wilayah tertentu dapat bersaing dengan perusahaan tempat lain dan bukan itu juga keunggulan kompetitif dapat digunakan untuk membangun lembaga keuangan yang lebih efisien dan mampu untuk menumbuhkan asset perusahaan yang spesifik (Kamukama, Ahiauzu, \& Ntayi, 2011). Penggunaan metode ini dapat membantu 
perusahaan untuk meningkatan nilai perusahaan yang mempengaruhi pengembalian dividen, keuntungan dan ukuran perusahaan.

Dampak terbesar persaingan bisnis itu sendiri terletak pada pendapatan perusahaan tersebut. Keuntungan merupakan salah sumber utama perusahaan untuk bertahan terhadap persaingan bisnis itu sendiri, selain mengandalkan investasi perusahaan. Pendapatan perusahaan dapat diketahui dengan menggunakan rasio profitabilitas yang dimana rasio ini dapat mengetahui kemampuan perusahaan dalam mendapatkan laba dalam hubungannya dengan penjualan, total aktiva maupun modal sendiri (Sartono, 2010: 122), sedangkan menurut Kasmir (2014:115) rasio profitabilitas merupakan metode untuk menilai kemampuan perusahaan dalam mencari keuntungan dan rasio ini juga dapat memberikan ukuran tingkat efektivitas manajemen pada suatu perusahaan. Penggunaan profitabilitas sebagai modal utaman akan berdampak pada efektivitas competitive advantage yang nantinya secara tidak langsung akan berdampak pada produktifitas dan peningkatan nilai perusahaan .tersebut.

Peningkatan nilai perusahaan secara umum dapat mempengaruhi berbagai item-item penting mengenai keuangan perusahaan terutama pada peningkatan ukuran perusahaan tersebut. Size perusahaan merupakan skala perusahaan yang dapat menentukan besarnya pendanaan dan kinerja perusahaan itu sendiri. Ukuran perusahaan dapat dibagai menjadi beberapa kelompok yaitu besar, menengah dan kecil. Ketiga kategori ukuran perusahaan tersebut dapat digunakan sebagai patokan untuk mengukur besar kecilnya suatu investasi.

Investor juga dapat melihat besarnya total asset, total penjualan, total capitalisme pasar yang nantinya dapat dijadikan rujukan dalam pengambilan keputusan mengenai investasi yang dilakukan oleh calon investor tersebut (Iturriaga \& Crisóstomo, 2010; Made, Gunawan, Pituringsih, \& Widyastuti, 2018; Naceur \& Goaied, 2002a). Melalui informasi ini investor akan lebih mudah dalam mengukur kemampuan perusahaan untuk mendapatkan keuntungan dan modal yang dimana hal ini dapat mencerminkan sebuah nilai perusahaan yang baik. Secara umum bila ukuran perusahaan meningkat maka dapat dikatakan perusahaan ini mempunyai nilai perusahaan yang tinggi, namun beberapa perusahaan di
Indonesia memiliki ukuran perusahaan yang tidak tinggi namun mereka mempunyai nilai perusahaan tinggi. Fenomena ini menunjukan bahwa perusahaan yang memiliki nilai perusahaan tinggi belum tentu memiliki ukuran perusahaan tinggi dan sebaliknya. Penjelasan ini membuktikan bahwa perusahaan membutuhkan pengelolahan atau pendanaan yang tepat untuk menjalankan usahanya dan hal ini sangat berpengaruh pada penilaian perusahaan dan pembagian dividen.

Pembagian dividen merupakan kewajiban setiap perusahaan terhadap pemegang sahamnya yang nantinya dari pembagian dividen tersebut dapat diketahui tingkat keefektifan perusahaan dalam mengelolah perusahaan. Dividen menurut Halim (2007:16) "dividen merupakan pembagian keuntungan yang diberikan perusahaan penerbit saham atas keuntungan yang diperoleh perusahaan". Sebelum melakukan pembagian dividen perusahaan harus melakukan pengukuran keuntungan investasi itu sendiri, karena pengukuran itu akan mempermudah perusahaan dalam menentukan besarnya pembagian dividen kepada pihak investor tersebut dan keuntungan investasi ini juga dapat disimpan oleh perusahaan yang nantinya bisa digunakan untuk melakukan reinvestasi menguntungkan bagi perusahaan (Mahdzan, Zainudin, \& Au, 2017). Tujuan utama melakukan reinvestasi adalah untuk membayar hutang perusahaan yang ada dan hal itu dapat merugikan perusahaan bila tidak dapat mengelolah dengan baik, sehingga dapat berdampak burung bagi perkembangan nilai perusahaan.

Pemegang saham atau investor juga mempunyai tujuan utama dalam melakukan investasi yaitu mengharapkan dividen dari saham tersebut dan mengharapkan capital gain. Keuntungan tersebut dapat berpengaruh terhadap perkembangan nilai perusahaan. Nilai perusahaan merupakan nilai jual sebuah perusahaan sebagai suatu bisnis yang sedang beroperasi dan adanya kelebihan nilai jual diatas nilai likuidasi (Sartono, 2010:487), sehingga dengan penambahan jumlah ekuitas dengan hutang perusahaan, maka dapat mencerminkan nilai. Fenomena naik turutnya nilai perusahaan belakangan ini sangatlah merugikan investor dan pemegang saham, dikarenakan banyak perusahaan yang tidak mengeluarkan dividen pada tahun 2018. Hal 
tersebut membuat keadaan nilai perusahaan menjadi tidak stabil.

Permasalahan ini membuat banyak perusahaan mengalami kerugian dan sejumlah perusahaan LQ 45 yang mengalami penurunan kinerja harus digantikan dengan perusahaan yang memiliki kinerja baik. Hal ini menunjukan bahwa perusahaan sangat memerlukan sebuah investasi yang besar agar perusahaan dapat memiliki kinerja yang stabil. Secara umum perusahaan menggunakan alat pengukuran yaitu economic value added (EVA), price book value (PBV), market book to ratio (MBR), tobin's Q (Weston dan Copeland, 1994). Empat metode ini merupakan teknik yang paling sering digunakan untuk mengukur kinerja perusahaan khususnya nilai perusahaan.

Penurunan atau fluktuatifnya kinerja perusahaan yang mencerminkan nilai perusahaan disebabkan oleh gejolak global dan menurunnya perekonomian Indonesia. Dampak itu terlihat pada pembagian dividen yang dimana banyak perusahaan tidak mengeluarkan dividen dan lebih memilih untuk melakukan reinvestasi untuk membayar hutang perusahaan, selain itu perusahaan terlalu banyak dalam melakukan hutang sehingga merugikan pihak perusahaan. Hal ini menyebabkan terjadinya penurunan kinerja pada perusahaan tersebut.

Alasan utama peneliti memilih variabel penelitian ini dikarenakan metode ini mempunyai pengaruh yang dapat membuat kinerja menjadi lebih baik. Indonesia mempunyai beberapa perusahaan besar yang terbagi di berbagai macam sektor industry. Selain itu masih banyak perusahaan yang melakukan trade off dan belum bisa mengelolah keuntungan dengan baik, sehingga perusahaan menggunakan dana eksternal untuk melakukan pendanaan pada perusahaan.

Secara umum perusahaan di Indonesia dalam melakukan pendanaan selalu memaksimalkan dana eksternal perusahaan atau melakukan hutang kepada bank. Hutang perusahaan terkadang dapat membuat nilai perusahaan menurun dikarenakan perusahaan harus membayar hutang dari keuntungan perusahaan itu sendiri. Penurunan nilai ini dapat berpengaruh pada kinerja perusahaan sehingga perusahaan membutuhkan penilaian dengan variabel penelitian ini dan selain itu peneliti juga tertarik untuk mengetahui pengaruh metode-metode tersebut dalam meningkatkan nilai perusahaan, mengingat masih banyak perusahaan yang melakukan hutang atau trade of dan mengalami kerugian di bursa saham Indonesia karena tidak bisa mengelolah keuangan dengan baik.

Berdasarkan penjelasan tersebut maka dapat disimpulkan bahwa penggunaan profitabilitas, ukuran perusahaan dan kebijakan dividen ini belum tentu dapat mempengaruhi nilai perusahaan. Hal ini tergantung pada pihak manajer dalam mengelolah faktor-faktor yang mendukung besarnya peningkatan nilai perusahaan itu sendiri. Pihak investor sangat perlu untuk memperhatikan beberapa faktor yang dapat mempengaruhi keputusan investasi yang dilakukan oleh pihak pemegang saham terhadap perusahaan, dikarenakan hal ini sangat mempengaruhi keberhasilan investasi pada perusahaan tersebut.

\section{KAJIAN PUSTAKA}

Penelitian oleh Amidu \& Abor (2006) ; Fama (1978); Naceur \& Goaied (2002b) profitabilitas mempengaruhi nilai perusahaan. Pengaruh tersebut dapat diartikan bahwa dengan memiliki kontrol yang baik pada keuntungan maka dapat berpengaruh terhadap nilai perusahaan sedangkan dengan banyaknya hutang maka akan berdampak pada nilai perusahaan yang negative. Hal ini menunjukan bahwa rasio profitabilitas dapat memperhitungkan kemampuan perusahaan dalam mendapatkan laba atau keuntungan perusahaan yang nantinya perhitungan ini dapat digunakan sebagai landasan untuk melihat nilai perusahaan. Hubungan positif ini dapat dimanfaat oleh pihak perusahaan untuk digunakan sebagai sarana pendanaan internal perusahaan, sehingga dengan memanfaatkan biaya internal maka ukuran perusahaan akan terus meningkat dan berdampak pada nilai perusahaan.

Ukuran perusahaan secara umum dapat mempengaruhi keunggulan dan penarikan investor pada perusahaan terkait, namun hal itu belum tentu berhasil bila perusahaan tidak mempunyai kinerja yang sehat. Penelitian menurut Liu et al., (2019) yang menggunakan prosedur pengukuran oleh Fama dan French (1993) dalam mengetahui kondisi perekonomian menyatakan pencipataan nilai perusahaan dapat tercipta dari rasio pendapatan yang di lihat melalui book to market dalam kaitan dengan pengaruh ukuran perusahaan, hal ini menunjukan bahwa ukuran perusahaan berpengaruh signifikan terhadap nilai 
perusahaan. Namun bila rasio pendapatan tidak stabil maka nilai sebuah perusahaan akan turut. Penelitian Leite, Klotzle, Pinto, \& da Silva (2018) jurnal ini menggunakan Fama \& French juga namun mereka menggunakan model yang lebih baik lagi dan hasil penelitian ini menunjukan nilai perusahaan akan menurun bila perusahaan menggunakan faktor profitabilitas, investasi dan ukuran perusahaan tidak berpengaruh signifikan terhadap nilai perusahaan, selain itu peneliti menemukan temuan atau bukti jelas mengenai efek ukuran dalam pengembalian stok rata-rata, efek profitabilitas dan beberapa efek investasi lainnya. Hal ini menunjukan bahwa ukuran perusahaan belum tentu bisa mendukung peningkatan nilai perusahaan dan faktor ukuran perusahaan ini dapat mempengaruhi pembagian dividen kepada pemegang saham itu sendiri. Pengaruh tersebut menunjukan bahwa semakin besar tingkatan ukuran perusahaan maka tingkat dividen yang dibagikan akan semakin meningkat seiring dengan meningkatnya investasi.

Peningkatan investasi ini secara umum dapat mempengaruhi besarnya dividen, dikarenakan semakin banyaknya saham yang dibeli oleh pihak investor maka perusahaan akan mendapatkan tingkat keuntungan yang tinggi juga. Penjelasan ini didukung oleh Amidu \& Abor (2006); Naceur \& Goaied (2002a) dividen berpengaruh positif terhadap nilai perusahaan, namun ada beberap faktor yang dapat membuat dividen menjadi negative yaitu faktor risiko, pemegang saham institusional, pertumbuhan dan market value. Penelitian mengenai dividen menurut Arko, Abor, K.D. Adjasi, \& Amidu, (2014) keputusan dividen dan pembagian dividen di pengaruhi oleh tingkat profitabilitas, peluang investasi, perpajakan, leverage, kepemilikan saham institusional, dan risiko perusahaan.

GAP hasil penelitian ini menunjukan bahwa walaupun pembagian dividen yang tinggi dapat mempengaruhi nilai perusahaan, namun masih bisa menjadi negative ketika perusahaan tidak dapat mengelolah faktorfaktor ini dengan baik. Perbedaan ini membuktikan bahwa tidak semua perusahaan yang mempunyai nilai perusahaan baik akan mendapatkan dividen yang tinggi, dan sebaliknya banyak perusahaan yang menyimpan dividen mereka untuk membayar hutang perusahaan dan pembayaran dividen. Permasalahan tersebut dapat berdampak terhadap peningkatan atau penurunan dividen yang nantinya bisa mengurangi jumlah investasi pada perusahaan tersebut.

Profitabilitas, ukuran perusahaan dan dividen merupakan alat bagi perusahaan untuk mempunyai nilai perusahaan yang tinggi dan sebagai sarana utama untuk mendapatkan investasi yang tinggi. Nilai perusahaan adalah cerminan harga saham dan juga dibentuk dari permintaan atau penawaran dari pihak investor (Fama, 1978; Harmono, 2012). Penjelasan ini menunjukan bahwa nilai perusahaan dapat terwujud berdasarkan besarnya keuntungan, ukuran dan dividen perusahaan itu sendiri yang berpengaruh terhadap ketertarikan investor terhadap perusahaan itu.

\section{Profitabilitas}

Setiap perusahaan memerlukan penilaian kinerja terutama pada tingkat keuntungan perusahaan. Penilaian ini sangat di butuhkan oleh perusahaan, karena dengan melakukan penilaian ini perusahaan akan mengetahui besarnya tingkat presentase perusahaan dan profitabilitas menurut Kasmir 2014: 122) menyatakan bahwa salah satu indikator untuk menilai kemampuan perusahaan dalam mencari keuntungan, sedangkan menurut Sartono (2010:122) menyatakan bahwa kemampuan perusahaan untuk memperloleh laba dalam kaitanya dengan penjualan, total aktiva ataupun modal sendiri. Keuntungan bagi perusahaan adalah komponen penting dalam mengelolah kinerja keuangan perusahaan dan rasio ini dapat digunakan sebagai pengukuran tingkat efektivitas keberhasilan perusahaan dalam mengukur kinerja perusahaan yang dapat mencerminkan nilai perusahaan.

Rasio ini dapat menghitung besarnya laba perusahaan dan profitabilitas sendiri merupakan alat ukur yang digunakan oleh perusahaan untuk menilai kemampuan perusahaan dalam mendapatkan laba (Made et al., 2018). Tingkat profitabilitas juga dapat menunjukan efek gabungan dari likuiditas, manajemen aset, dan utang pada hasil operasi sehingga kinerja perusahaan yang didapatkan akan optimal (Ehrhardt \& Brigham, 2009). Pengoptimalan kinerja perusahaan ini akan membuat tingkat keuntungan perusahaan menjadi berlebih dan dapat digunakan sebagai sumber dana internal sehingga perusahaan perlu untuk memaksimalkan keuntungannya. 
Dana internal ini dapat dikelolah dengan menggunakan ROA, ROE dan NPM yang nantinya hasil pengukuran tersebut bias dijadikan patokan untuk melakukan investasi. Berdasarkan penjelasan tersebut maka dapat disimpulkan bahwa profitabilitas merupakan rasio yang digunakan untuk mengukur tingkat keuntungan perusahaan sehingga tingkat keuntungan perusahaan tersebut dapat mencerminkan kondisi perusahaan. Tingkat keuntungan tersebut dapat dijadikan patokan oleh investor untuk melakukan investasi di perusahaan terkait. Rasio profitabilitas dapat digunakan sebagai tolak ukur dalam menilai kinerja perusahaan, sehingga dapat mencerminkan nilai perusahaan yang baik.

\section{Ukuran Perusahaan}

Ukuran perusahaan merupakan sebuah identitas pada perusahaan yang harus di ketahui oleh pihak investor maupun penyandang dana. Ukuran perusahaan adalah jumlah variasi kapasitas produksi dan kemampuan yang dimiliki perusahaan atau variasi layanan yang dapat diberikan perusahaan secara bersamaan kepada investor (Niresh \& Velnampy, 2014) sedangkan menurut Brigham \& Houston, ( 2013 ; 119) menyatakan bahwa ukuran perusahaan merupakan salah satu rata-rata total aktiva tahunan perusahaan terkait sampai dengan beberapa tahun mendatang. Penjelasan tersebut menunjukan bahwa total sales dan aktiva perusahaan dapat mempengaruhi nilai perusahaan.

Salah satu cara dalam meningkatkan nilai perusahaan yaitu dengan cara memaksimalkan ukuran perusahaan itu sendiri, karena dengan mengetahui ukuran perusahaan maka secara otomatis akan berdampak pada nilai perusahaan tersebut. Fakta ini menunjukan bahwa pihak terkait harus mengelolah perusahaan dengan baik dan informasi ini dapat membantu calon investor dalam mengambil keputusan investasi atau pendanaan. Penggunaan modal asing tersebut menunjukan bahwa semakin besarnya kebutuhan perusahaan yang nantinya hal itu akan berdampak pada peningkatan nilai investasi dan calon investor dapat mellihat ukuran perusahaan melalui total asset, total sales dan nilai kapitalisasi pasar yang nantinya kegiatan itu dapat mencerminkan nilai dan ukuran perusahaan tersebut.

\section{Kebijakan Dividen}

Setiap perusahaan besar tentunya memiliki dividen apa bila perusahaan itu memiliki saham yang dijual di bursa saham. Dividen menurut Harmono (2012; 12) menyatakan bahwa merupakan presentase laba yang dibayarkan kepada pemegang saham dalam bentuk dividen tunai, stabilitas dividen waktu ke waktu, pembagian dividen saham dan pembelian kembali saham. Secara umum setiap perusahaan harus membagikan dividennya kepada pihak investor atau pemegang saham yang nantinya hal itu adalah kewajiban perusahaan untuk membagikan keuntungannya kepada pihak investor. Pembagian dividen ini dapat dijadikan sebuah informasi oleh calon investor sebelum melakukan investasi.

\section{Tingkat keuntungan dividen} perusahaan ini ternyata dapat disimpan oleh perusahaan dan tingkat keuntungan itu dapat dijadikan modal utama untuk melakukan investasi, karena menurut Mahdzan et al., (2017) menyatakan bahwa kebijakan dividen berkaitan dengan keputusan manajemen tentang berapa banyak pendapatan perusahaan yang harus dibayarkan kepada pemegang saham sebagai dividen dan mempertahankan dana dividen yang ada untuk melakukan reinvestasi. Reinvestasi tersebut dilakukan agar perusahaan dapat memperoleh keuntungan dari hasil investasi perusahaan, sehingga dividen yang dikeluarkan oleh perusahaan dapat di bagi secara optimal kepada pemegang saham atapun investor perusahaan. Tingkat pengembalian dividen berupa ekuitas ini dapat meningkatkan pembayaran dividen perusahaan (Lintner, 1956).

Sebelum melakukan pembagian dividen perusahaan harus melakukan penilaian terhadap keuntungan, hal itu dilakukan agar perusahaan tidak mengalami kerugian. Alat ukur yang digunakan oleh perusahaan yaitu menggunakan DPR, DPS dan dividen yield sebagai indikator penilaian itu (C. Arko et al., 2014). Berdasarkan penjelasan tersebut maka dapat disimpulkan bahwa kebijakan dividen merupakan kebijakan yang mengatur mengenai pembagian pembayaran hasil investasi perusahaan. Pembayaran dividen tersebut dapat mempengaruhi harga saham perusahaan yang dimana pembagian dividen yang dilakukan oleh perusahaan dapat mencerminkan kinerja perusahaan yang baik dan pembayaran itu dapat mengurangi resiko kegagalan tingkat pengembalian saham terhadap pemegang 
saham. Tingkat keuntungan dividen ini dapat digunakan oleh perusahaan untuk melakukan reinvestasi yang nantinya dapat digunakan sebagai sumber dana internal perusahaan yang digunakan untuk melakukan investasi ulang dan pendanaan kebutuhan operasional perusahaan tersebut.

\section{Nilai Perusahaan}

Setiap perusahaan tentunya memilik sebuah tujuan yaitu mempunyai nilai perusahaan yang baik. Nilai perusahaan tersebut dapat dilihat dari besarnya keuntungan, tingkat investasi dan pembagian dividen perusahaan setiap tahunnya sedangkan menurut (Fama, 1978) menyatakan bahwa nilai perusahaan dapat dilihat dari harga sahamnya. Harga saham tersebut dapat terbentuk dari permintaan, penawaran investor sehingga harga saham ini dapat dijadikan sebagai patokan untuk melihat nilai perusahaan. Selain itu, bila ingin mendapatkan nilai perusahaan yang baik dapat menggunakan cara yaitu dengan menentukan suatu kombinasi sumber dana yang sedemikian rupa yang mampu digunakan sebagai pondasi pembentukan modal.

Pembentukan modal ini akan berimbas pada pemaksimalan nilai perusahaan, karena menurut Jensen (2001) menyatakan bahwa untuk memaksimalkan nilai perusahaan tidak hanya nilai ekuitas saja yang harus diperhatikan namun sumber keuangan seperti hutang maupun saham preferennya juga harus diperhatikan. Faktor tersebut menunjukan untuk memaksimalkan nilai perusahaan tidak harus menggunakan modal sendiri tetapi dapat menggunakan harga saham, saham preferen, tingkat keuntungan dan hutang perusahaan.

Nilai perusahaan juga membutuhkan pengukuran yaitu menurut Weston dan Copeland, (1994) menyatakan bahwa rasiorasio penilaian nilai perusahaan merupakan ukuran perusahaan yang paling menyeluruh untuk menilai kinerja suatu perusahaan karena dapat mencerminkan pengaruh gabungan dari hasil pengembalian dan risiko. Selain ada tiga rasio yang digunakan untuk menghitung nilai yaitu pricel earning ratio (rasio harga/laba), Market to book ratio, Tobin's $Q$ ratio (rasio tobin). Rasio tersebut merupakan metode yang paling sering digunakan untuk menilai kinerja perusahaan ataupun nilai perusahaan. Hasil perhitungan ini dapat digunakan sebagai patokan oleh perusahaan maupun investor untuk melakukan investasi dan pendanaan perusahaan terkait.

Berdasarkan penjelasan tersebut, maka dapat disimpulkan bahwa nilai perusahaan merupakan cerminan kondisi perusahaan yang dimana kondisi tersebut dapat mempengaruhi perusahaan dalam mendapatkan calon investor. Calon investor ingin mengetahui nilai perusahaan dengan cara melihat harga saham perusahaan. Keputusan tersebut penting dilakukan agar investor dalam melakukan investasi dapat mengurangi risiko invetasi yang ada. Pengurangan risiko tersebut sangatlah penting untuk perusahaan, sebab dengan mengurangi risiko tersebut perusahaan akan lebih mudah dalam menjalankan perusahaannya dan dampak pengurangan risiko itu akan membuat pendanaan perusahaan semakin meningkat dikarenakan perusahaan tidak terbebani oleh besarnya tingkat investasi.

\section{Pengaruh Antar Variabel Profitabilitas Terhadap Nilai Perusahaan} Pengaruh tingkat keuntungan terhadap nilai perusahaan merupakan hubungan yang saling mempengaruhi satu sama lain yang nantinya pengaruh tersebut dapat meningkatkan dan menurunkan nilai perusahaan, hal tersebut tergantung pada perusahaan dalam mengelolah tingkat keuntungan tersebut. Kajian empiris menurut mengatakan (Amidu \& Abor, 2006a; El-Sayed Ebaid, 2009; Made et al., 2018; Naceur \& Goaied, 2002b) bahwa profitabilitas berpengaruh singnifikan terhadap nilai perusahaan. Pernyataan tersebut menunjukan bahwa dengan tingginya tingkat keuntungan yang diterima oleh perusahaan secara otomatis akan berdampak pada nilai perusahaan, selain itu juga dengan meningkatnya nilai perusahaan tersebut akan mengundang banyak investor untuk melakukan investasi di perusahaan terkait.

\section{Ukuran Perusahaan Terhadap Nilai Perusahaan}

Firm size bagi perusahaan merupakan identitas utama yang dapat digunakan untuk mengukur besarnya skala ukuran perusahaan. Skala ukuran ini adalah informasi penting bagi investor untuk melakukan investasi. Semakin besar ukuran sebuah perusahaan maka firm value akan meningkan. Kajian empris menurut (Leite et al., 2018; Liu, Stambaugh, \& Yuan, 2019; Made et al., 2018; Naceur \& Goaied, 2002b) menyatakan bahwa firms size berpengaruh signifikan terhadap firms value. 
Hasil penelitian terdahulu tersebut menjelaskan bahwa dengan semakin besarnya skala perusahaan tersebut, maka nilai perusahaan akan meningkat dikarenakan perusahaan dapat mengoptimalkan ukuran perusahaan.

\section{Kebijakan Dividen Terhadap Nilai Perusahaan}

Kebijakan dividen bagi perusahaan merupakan hal yang sangat penting untuk dipahami, karena dividen tersebut adalah parameter keberhasilan perusahaan dalam mengembalikan modal kepada investor yang nantinya pembagian dividen akan menjadi informasi penting bagi calon investor untuk berinvestasi. Keberhasilan perusahaan dalam membagikan dividen ini akan membuat proposi perusahaan meningkat yang disebabkan perusahaan dapat membagikan dividen setiap tahunnya dan perusahaan akan mempunyai prospek yang relatif lebik baik dalam jangka waktu tertentu. Pengelolahan kebijakan dividen yang baik akan meningkatkan nilai perusahaan, sehingga perusahaan harus mengoptimalkan dividen yang ada agar nilai perusahaan dapat meningkat.

Kajian empiris pada penelitian terdahulu yaitu menurut (Alonso et al., 2005; Amidu \& Abor, 2006; Ghosh, 2008; C. Arko et al., 2014; Made et al., 2018) menyatakan bahwa dividen berpengaruh signifikan terhadap firms value.

Berikut merupakan model hipotesis pada penelitian konseptual ini :

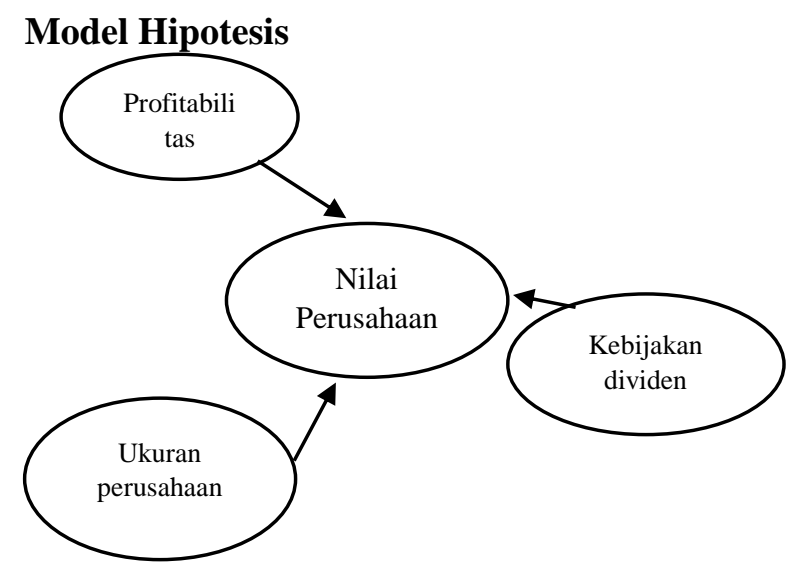

Gambar 1 . Model Hipotesis

Sumber : data diolah, 2020

Proposisi :

P1 : Profitabilitas yang meningkat dapat meningkatkan nilai perusahaan.
P2 : Ukuran perusahaan perusahaan yang tinggi dapat meningkatkan nilai perusahaan.

P3 : Kebijakan dividen dapat meningkatkan nilai perusahaan.

\section{METODE PENELITIAN}

Penelitian ini menggunakan explanatory research dengan pendekatan kuantitatif. menurut Singarimbun \& Effendi (2008:4) menjelaskan explanatory research merupakan penelitian yang digunakan untuk menjelaskan hubungan kausal antara variabel-variabel melalui pengujian hipotesa yang dirumuskan atau sering kali disebut sebagai penelitian penjelas. Jenis penelitian ini dapat digunakan untuk menjelaskan faktor-faktor yang mempengaruhi fenomena atau permasalahan yang menjadi topik penelitian tersebut, sehingga dengan mengetahui faktor-faktor yang mempengaruhi fenomena ini, maka peneliti dapat menarik sebuah kesimpulan yang berdasarkan pada hasil penelitian tersebut. pendekatan ini merupakan metode ilmiah karena telah memenuhi kaidah ilmiah yaitu empiris, objektif, terukur,sistematis dan data penelitian berupa angka-angka yang diolah menggunakan metode statistik (Sugiyono 2014:12). Pendekatan kuantitatif ini mempunyai prosedur penelitian yang menghasilkan data ril berupa angka dan dapat diukur dengan pasti.

\section{Objek Penelitian}

Objek penelitian pada konseptual penelitian ini mneggunakan IDX LQ 45 yang terdaftar di BEI tahun 2015-2018.

\section{Populasi Dan Sampel}

Populasi ppqelitian ini sebanyak 45 perusahaan yang nantinya dapat ditarik sampel dengan menggunakan purpose sampling dan teknik ini menggunakan karakteristik dalam pengambilan samplenya. Berikul merupakan karakteristik pengambilan sample pada konspetual penelitianpingi :

a. Perusahaan IDX LQ 45 yang terdaftar di Bursa Efek Indonesia empat tahun berturut-turut yaitu periode 2015-2018.

b. Perusahaan tersebut menerbitkan laporan keuangan yang telah diaudit, lengkap dan dipublikasikan selama 4 tahun berturut-turut yaitu tahun 20152018.

c. Perusahaan mengeluarkan dividen selama 4 tahun yaitu tahun 2015-2018. 


\section{Sumber Dan Jenis Data}

Pengambilan data diambil melalui web site BEI yaitu idx.com. Jenis data penelitian ini menggunakan data sekunder, sehingga peneliti mengambil data berupa laporan tahunan, anuel repot dan harga saham perusahaan terdaftar.

\section{Identifikasi Variabel Dan Definisi Operasional}

Berikut merupakan variable pada konseptual penelitian ini :

1. Variable eksogen

a. Profitabilitas (X1)

1) ROA

2) ROE

3) NPM

b. Ukuran Perusahaan (X2)

1) Total Sales

2) Total Asset

3) Nilai kapitalisasi pasar

c. Kebijakan Dividen (X3)

1) Divden yied

2) DPS

3) DPR

2. Variable Endogen

a. Nilai Perusahaan (Y1)

1) Market Book To Ratio

2) Market Book To Asset

3) Tobin's $Q$

4)

\section{Lokasi Penelitian}

Lokasi penelitian ini bertempat pada Galeri Bursa Efek Indonesia Fakultas Ekonomi Dan Bisnis Universitas Brawijaya Malang Jl. MT Haryono185 Malang. Alasan pengambil data dilokasi tersebut dikarenakan data yang dibutuhkan lengkap dan mudah untuk diakses oleh peneliti. Data yang diperlukan berupa laporan keuangan telah dipublikasikan selama 4 tahun yaitu periode 2015-2018 beserta ICMD (Indonesian Capital Market Directory), laporan tahunan perusahaan dari www.idx.com.

\section{Teknik Pengumpulan Data}

Teknik pengumpulan data pada penelitian ini menggunakan teknik dokumentasi dengan melihat, merekam dan menyalin dalam bentuk laporan keuangan.

\section{Metode Analisis Data}

Analisis data digunakan untuk mengelolah data mentah agar lebih bermakna dalam penyajiannya sehingga bisa memberikan alternatif pemecahan masalah dari penelitian yang dilakukan Penelitian ini menggunakan analisis data berupa :
a. Analisis Deskripsi
b. Analisis Statistik Inferensial

Dan metode pengelolahan data penelitian ini menggunakan software smart PLS 3.0.

\section{KESIMPULAN DAN SARAN Kesimpulan}

Berdasarkan hasil review tersebut maka dapat disimpulkan bahwa secara teori mendunkung ke tiga proposisi tersebut. Penelitian ini menunjukan bahwa setiap kegiatan perusahaan tersebut memiliki peran dan dampak yang dapat meningkatkan nilai perusahaan. Peran tersebut sangat diperlukan oleh perusahaan agar perusahaan ini memiliki kinerja yang baik sehingga dapat menarik investor untuk melakukan investasi menguntungkan bagi perusahaan. Hasil review ini juga menemukan beberapa faktor penting dan GAP yang nantinya dari hasil pemahaman tersebut dapat ditemukan hal yang dapat membantu perusahaan dalam menjalankan kinerjanya.

GAP teori ini menunjukan bahwa tidak semua metode yang digunakan dalam menjalankan perusahaan dapat berpengaruh. Pengaruh ini tergantung pada perusahaan dalam mengahadapi perkembangan perekonomian pada negara tersebut. Perusahaan perlu memahami karakteristik faktor-faktor yang mempengaruhi kinerja perusahaan dan nilai perusahaan.

Faktor tersebut merupakan item-item yang berpengaruh terhadap pembayaran dividen. Faktor ini berupa keputusan dividen dan pembagian dividen yang dipengaruhi oleh tingkat profitabilitas, peluang investasi, perpajakan, leverage, kepemilikan saham institusional, dan risiko perusahaan dan penelitian yang dikemukakan oleh Leite et al., (2018) menyatakan bahwa ukuran perusahaan tidak berpengaruh signifikan terhadap nilai perusahaan. Pernyataan tersebut menunjukan bahwa item-item keuangan ini belum cukup efektif dalam menaikan kinerja perusahaan dan pengaruh keefektifan itu sangat dipengaruhi oleh kondisi perekonomian dan keuangan perusahaan.

\section{Saran}

Berdasarkan pembahasan konseptual penelitian ini maka peneliti dapat memberikan saran sebagai berikut : 
1. Peneliti menyarankan bagi pembaca untuk menggunakan variable lain mengenai kinerja perusahaan yang dapat mencerminkan nilai perusahaan.

2. Peneliti menyarankan bagi perusahaan untuk mengetahui faktorfaktor yang mendukung pembagian dividen.

3. Peneliti menyarankan untuk mencari teori yang tepat agar untuk diaplikasikan pada permasalahan penelitian.

4. Peneliti menyarankan untuk memahami faktor-faktor yang dapat mempengaruhi peningkatan nilai perusahaan.

\section{DAFTAR PUSTAKA}

Alonso, P. de A., Iturriaga *, F. J. L., \& Sanz, J. A. R. (2005). Financial decisions and growth opportunities: a Spanish firm's panel data analysis. Applied Financial Economics, 15(6), 391-407. https://doi.org/10.1080/09603100500039 201

Amidu, M., \& Abor, J. (2006a). Determinants of dividend payout ratios in Ghana. Journal of Risk Finance, 7(2), 136-145. https://doi.org/10.1108/15265940610648 580

Amidu, M., \& Abor, J. (2006b). Determinants of dividend payout ratios in Ghana. Journal of Risk Finance. https://doi.org/10.1108/15265940610648 580

Brigham, E. F., \& Houston, J. F. (2013). Dasar-Dasar Manajemen Keuangan. Salemba Empat. https://doi.org/10.1145/2505515.2507827

C. Arko, A., Abor, J., K.D. Adjasi, C., \& Amidu, M. (2014). What influence dividend decisions of firms in SubSaharan African? Journal of Accounting in Emerging Economies. https://doi.org/10.1108/jaee-12-20110053

El-Sayed Ebaid, I. (2009). The impact of capital-structure choice on firm performance: empirical evidence from Egypt. The Journal of Risk Finance, 10(5), 477-487. https://doi.org/10.1108/15265940911001 385

Fama, E. F. (1978). The effects of a firm's investment and financing decisions on the welfare of its security holders. American Economic Review.

Ghosh, S. (2008). Do Leverage, Dividend Policy and Profitability Influence Future Value of Firm? Evidence from India. SSRN Electronic Journal. https://doi.org/10.2139/ssrn.1158251

Harmono. (2012). Testing of Pecking Order Theory Through the Relationship : Earnings , Capital Structure, Dividend Policy, and Firm' S Value. Keuangan Dan Perbankan.

Ibhagui, O. W., \& Olokoyo, F. O. (2018). Leverage and firm performance: New evidence on the role of firm size. North American Journal of Economics and Finance. https://doi.org/10.1016/j.najef.2018.02.00 2

Iturriaga, F. J. L., \& Crisóstomo, V. L. (2010). Do leverage, dividend payout, and ownership concentration influence firms' value creation? an analysis of Brazilian firms. Emerging Markets Finance and Trade. https://doi.org/10.2753/REE1540496X460306

Jensen, M. (2001). Value maximisation, stakeholder theory, and the corporate objective function. European Financial Management. https://doi.org/10.1111/1468-036X.00158

Kamukama, N., Ahiauzu, A., \& Ntayi, J. M. (2011). Competitive advantage: Mediator of intellectual capital and performance. Journal of Intellectual Capital. https://doi.org/10.1108/14691931111097 953

Kasmir. (2014). Bank dan Lembaga Kuangan Lainnya. PT. Raja Grafindo Persada jakarta.

Leite, A. L., Klotzle, M. C., Pinto, A. C. F., \& da Silva, A. F. (2018). Size, value, profitability, and investment: Evidence from emerging markets. Emerging Markets Review. https://doi.org/10.1016/j.ememar.2018.04 .006 
Lintner, J. (1956). Distribution of incomes of corporations among dividends, retained earnings, and taxes. The American Economic Review.

https://doi.org/10.1126/science.151.3712. $867-\mathrm{a}$

Liu, J., Stambaugh, R. F., \& Yuan, Y. (2019). Size and value in China. Journal of Financial Economics. https://doi.org/10.1016/j.jfineco.2019.03. 008

Made, I., Gunawan, A., Pituringsih, E., \& Widyastuti, E. (2018). the Effect of Capital Structure, Dividend Policy, Company Size, Profitability and Liquidity on Company Value (Study At Manufacturing Companies Listed on Indonesia Stock Exchange 2014-2016). International Journal of Economics, Commerce and Management United Kingdom.

Mahdzan, N. S., Zainudin, R., \& Au, S. F. (2017). The adoption of Islamic banking services in Malaysia. Journal of Islamic Marketing. https://doi.org/10.1108/JIMA08-2015-0064

Naceur, S. Ben, \& Goaied, M. (2002a). The relationship between dividend policy, financial structure, profitability and firm value. Applied Financial Economics, 12(12), 843-849. https://doi.org/10.1080/09603100110049 457

Naceur, S. Ben, \& Goaied, M. (2002b). The relationship between dividend policy, financial structure, profitability and firm value. Applied Financial Economics, 12(12), 843-849.

https://doi.org/10.1080/09603100110049 457

Niresh, J. A., \& Velnampy, T. (2014). Firm Size and Profitability: A Study of Listed Manufacturing Firms ed Manufacturing Firms in Sri Lanka. International Journal of Business and Management. https://doi.org/10.5539/ijbm.v9n4p57

Singarimbun, Masri dan Sofian Effendi, Metode Penelitian Survei, Jakarta: LP3ES, 2008.
Anonim. Laporan keuangan dan laporan tahunan. Diakses 7 November 2019 dari www. dx. co.id 